\title{
Salaried Vs. Self-Employed: A Study On The Factors Influencing Investment Patterns
}

\author{
Dr.D.Kavitha ${ }^{1}$, Ms.Vyshally A ${ }^{2}$ \\ $\left\{\right.$ kavitha@psgim.ac.in ${ }^{1}$, vyshally.anandan@gmail.com ${ }^{2}$ \} \\ Associate Professors, PSG Institute of Management, India ${ }^{1}$. Student, PSG Institute of Management, \\ India. $^{2}$
}

\begin{abstract}
The Individuals make investments to achieve their financial objectives. The availability of several traditional and new investment avenues in the current context provides a wide range of options at all risk levels. Traditionally it has been considered that the investment preferences, objectives and factors influencing investment vary between the salaried and the self-employed. This study was undertaken to understand if there are differences between the two categories of respondents. The study was conducted in Coimbatore District, India with 410 respondents. The study found that fixed deposits were the preferred investment option whereas high-risk avenues such as crypto and derivatives were the least preferred. The study also found that the two respondent groups differ significantly in their investments.
\end{abstract}

Keywords: Investment, Influencing factors, investment avenues, Salaried, Selfemployed.

\section{Introduction}

Investments not only maximize the wealth for an individual but also are vital for capital formation and economic development of a nation. The investment facilitates financial independence of individuals by increasing the wealth, fulfilling personal goals and reducing futurerisk. The fast paced growth in technology has opened up several new avenues for investment along with traditional investment channels. Each avenue has its own level of risk and investors make their choice based on their risk-appetite. The risk-taking ability is influenced by various factors such as income, socio-economic status, education family size and occupation. Also, the extent of awareness about the investment choices and the perceptions of investors on the risk and return of the options play a significant role in investment decisions. This study identifies how these factors change or set the decision making process of the investors.

\section{Objectives of the Study}

This study seeks to

- Identify the factors influencing investment pattern of salaried and self-employed individuals in Coimbatore 
- Understand the preferred channels of investment

\section{Literature Review}

The factors influencing investment is both an internal \& external factor. Several studies have found that demographic factors are significant determinants of investment decisions (Chaurasia, 2017; Kumawat and Parkar, 2020). Among them the education of the investor and their occupation decides a major part of their investment decision. Investment preferences of individuals are influenced by their occupation (Bhatt and Bhatt, 2012) and income (Ramanujam and Chitradevi, 2012). The study also found that the extent of scrutiny about a particular investment avenue is also driven by the occupation of the respondent. Gender has also been found to be a significant factor influencing investment decisions (Bajtelsmit, \& Bemasek, 1996) as psychological differences between men and women differ. Therisk preference and risk tolerance level is determined not just on income but also on how the psychological factors affect the investment decision-making process. Besides gender, culture, socio-cultural factors and consumption levels werealso found to influence the behavior of Indianinvestors (Ramanujam and Chitradevi, 2012; Jain and Joy, 1997).Everyindividual'srisktolerancedifferswhen being alone than in those of groups. When in groups an individual's decision making is infleucned by the members of the group. The possibility to observe the others and make wise choices is available when an individual is a part of a group. Learning from the mistakes of others is an added advantage in such circumstances (Viscusi et al., 2011).

Studies examining investment in stocks have found that historical stock performance, dividend and bonus announcements, possibility of quick growth and stock-splits as the most influencing factors on investment decisions. Attempt to investigate the importance of certain external factors on the investment decision has made in (Bialowolski and WeziakBialowolska, 2013) found that law-related factors and expected future developmentsof an economy impacted investment pattern (Antonides and Van Der Sar, 1990).

Studies examining the preferred investment choices in India have found that fixed deposits, debt instruments (Chaurasia, 2012), purchase of home (Shukla, 2016), gold are the most preferred investment choices. However, as financial literacy increases the choice of investment was also found to broaden to more risky options such as mutual funds and equity investments (Awais et al., 2016).

\section{Methodology}

The research is descriptive in nature. Since the research is about investment behavior ofsalaried and self- employed investors regardless of their income or education level, the population consists of all the self-employed and salaried individuals in Coimbatore District. Convenient sampling technique was used to select the respondents based on the convenience of the study. The final sample for the study consisted of 410 respondents. The demographic profile of the respondents is presented in Table 1.

The first step in the study was the design of the questionnaire to be used for data collection. A focus group was done with 10 experts who were aware of the numerous investment options to prune the questionnaire to be used for the study. These experts were 
financialconsultants. The final questionnaire consisted of questions related to the demographic variables and the various aspects of respondent's income, awareness on investment avenues, societal factors, their age and occupation.

Table 1: Demographic Profile of the Respondents

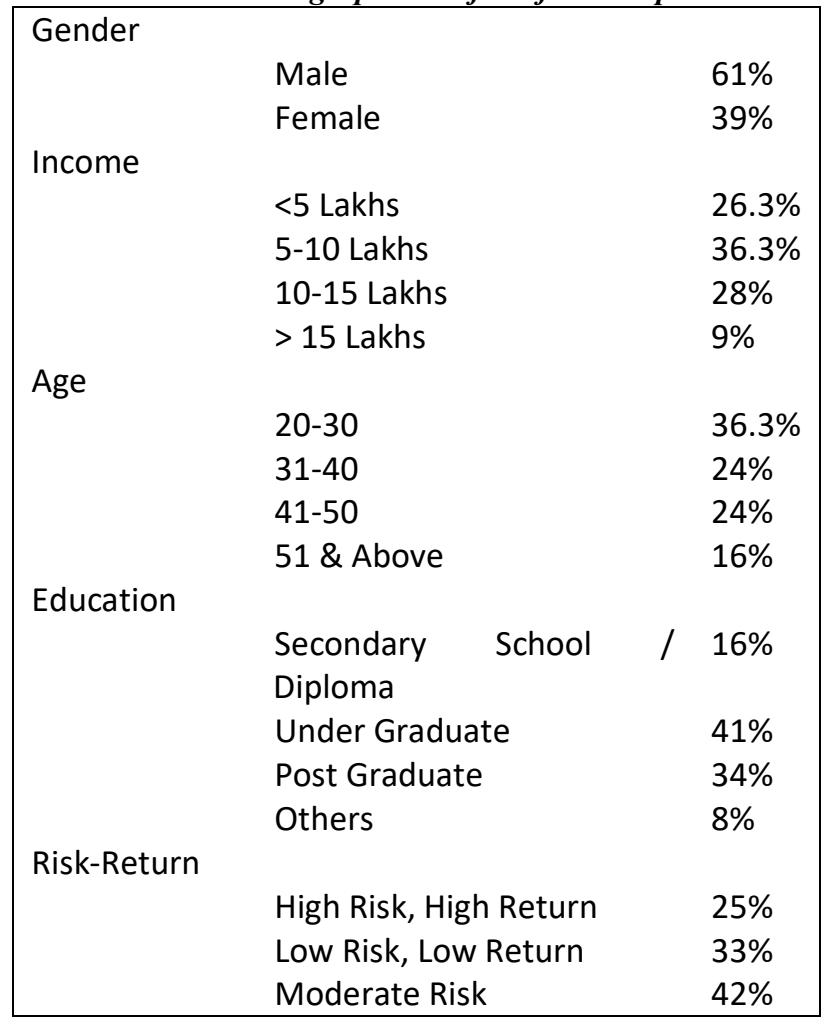

\section{Analysis and Results}

An analysis of the investments made by the respondents (Table 2) shows that higher investments was made by respondents the age group of 41-50 years. They are financially settled so the investment percentage also rises in relation to their income earned. Also, respondents in the highest income bracket also had higher proportion of their income allotted to investments. Among the investors earning $<5$ lakh, around $2 \%$ do nott invest as they have just started their earning. Also, it is evident that not all investors increase their investment as their income increases. 
Table 2: Percentage of Investments

\begin{tabular}{|c|c|c|c|}
\hline .865 & FNW & \multirow{3}{*}{ 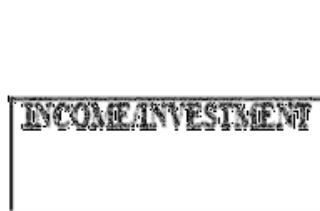 } & \multirow{3}{*}{ NVWSTHN (W) } \\
\hline 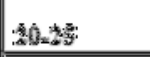 & 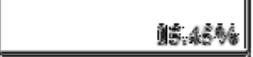 & & \\
\hline .26 .30 & 16.56\% & & \\
\hline $3 \overline{3}=35$ & $206 \%$ & 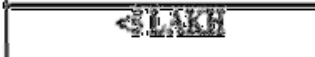 & 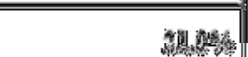 \\
\hline Ses: & 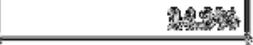 & 2. & 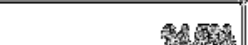 \\
\hline 整。积 & 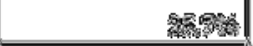 & 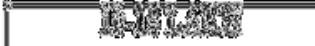 & 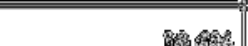 \\
\hline 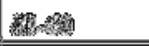 & 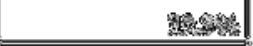 & 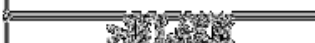 & \\
\hline 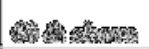 & 20 & & wat \\
\hline
\end{tabular}

Table 3: Preferred Investment Avenues

\begin{tabular}{|c|c|c|c|c|}
\hline \multirow[b]{2}{*}{ AGE } & \multicolumn{2}{|c|}{ Self-Employed } & \multicolumn{2}{|l|}{ Salaried } \\
\hline & \begin{tabular}{|l|} 
Avg. \\
Investment \\
$(\%)$ \\
\end{tabular} & $\begin{array}{l}\text { Major Investment } \\
\text { Avenues }\end{array}$ & $\begin{array}{l}\text { Avg. } \\
\text { Investme } \\
\text { nt (\%) } \\
\end{array}$ & $\begin{array}{|ll|}\begin{array}{l}\text { Major } \\
\text { Avenues }\end{array} \\
\end{array}$ \\
\hline $20-25$ & $20.0 \%$ & Deposit, shares & $9.3 \%$ & Deposit, gold \\
\hline $26-30$ & $24.3 \%$ & Deposit, insurance & $11.4 \%$ & $\begin{array}{l}\text { Deposit, insurance, } \\
\text { mutual } \\
\text { fund }\end{array}$ \\
\hline 31-35 & $24.9 \%$ & $\begin{array}{l}\text { Mutual fund, } \\
\text { insurance, } \\
\text { estate }\end{array}$ & $12.1 \%$ & Deposit, shares \\
\hline $36-40$ & $8.9 \%$ & Insurance & $13.6 \%$ & $\begin{array}{l}\text { Deposit, insurance, } \\
\text { mutual } \\
\text { fund }\end{array}$ \\
\hline $41-50$ & $31.1 \%$ & $\begin{array}{l}\text { Deposit, mutual } \\
\text { fund, } \\
\text { real estate }\end{array}$ & $18.0 \%$ & Deposit, insurance \\
\hline $51-60$ & $27.6 \%$ & Real estate, gold & $22.0 \%$ & Deposit, insurance \\
\hline
\end{tabular}

The major investment channel (Table 3) tends to be deposits \& insurance regardless ofage.Mutual fund has been a growing investment among the self-employed in the recentyears.Unlike other channels of investment, self-employed show a personal desire to increase their investment under real estate once they age and with an improvement in their income.

Factors Influencing Investment Decisions

Table 4: Factors Influencing Investors 


\begin{tabular}{|c|c|c|}
\hline FACTORS & $\begin{array}{l}\text { Self-employed } \\
\text { (Mean Value) }\end{array}$ & $\begin{array}{l}\text { Salaried } \\
\text { (Mean } \\
\text { Value) }\end{array}$ \\
\hline Newspaper / Media & 3.2 & 3.3 \\
\hline Friends \& Colleagues & 3.7 & 3.9 \\
\hline $\begin{array}{c}\text { Prior Investment } \\
\text { Experience }\end{array}$ & 4.3 & 3.1 \\
\hline Family & 4.1 & 2.9 \\
\hline Financial Advisor & 2.4 & 1.5 \\
\hline
\end{tabular}

Among both salaried and self-employed, the role of a financial advisor was limited in influencing the choice of investment avenues (Table 4). For the salaried respondents, friends and colleagues had the highest influence followed by newspaper and media. For the selfemployed, prior investment experience was found to be the largest influencer followed by family members.

\section{Reasons for Investments}

There was a stark contrast between the reasons for investment among the two category of respondents (Table 5). The self-employed were more oriented towards investments for the purpose of generating returns and tax savings. The salaried however had tax savings as the primary reason for their investment followed by purchase of house. Both the category of investors however considered health related issues as the least important reason.

Table 5: Reasons for Investments

\begin{tabular}{|l|c|c|}
\hline FACTORS & $\begin{array}{l}\text { Self-employed } \\
\text { (Rank) }\end{array}$ & $\begin{array}{l}\text { Salaried } \\
\text { (Rank) }\end{array}$ \\
\hline Returns & 1 & 3 \\
\hline Tax Savings & 2 & 1 \\
\hline Family Security & 3 & 4 \\
\hline Retirement Period & 4 & 5 \\
\hline Wealth Accumulation & 5 & 7 \\
\hline Education Reasons & 6 & 6 \\
\hline House & 7 & 2 \\
\hline Health Issues & 8 & 8 \\
\hline
\end{tabular}

Table 6: Investment Preference of Respondents

\begin{tabular}{|c|c|c|}
\hline FACTORS & $\begin{array}{l}\text { Self-employed } \\
\text { (Rank) }\end{array}$ & $\begin{array}{l}\text { Salaried } \\
\text { (Rank) }\end{array}$ \\
\hline Fixed Deposit & 1 & 1 \\
\hline Post Office Schemes & 7 & 2 \\
\hline Life Insurance & 2 & 3 \\
\hline Mutual Funds & 3 & 4 \\
\hline
\end{tabular}




\begin{tabular}{|l|l|l|}
\hline Stocks & 6 & 5 \\
\hline Gold / Silver & 4 & 6 \\
\hline Real Estate & 5 & 7 \\
\hline Debt Instruments & 8 & 8 \\
\hline Derivatives & 9 & 9 \\
\hline Crypto, Bit coin etc & 10 & 10 \\
\hline
\end{tabular}

An analysis of the preferred investment avenue (Table 6) showed that among both salaried and self-employed, Fixed deposits were the most preferred investment avenue. The salaried respondents were inclined towards post-office schemes whereas the self-employed did not show great interest towards the same. Riskier investments such as crypto, derivatives and debt instruments were not on the top of the priority list for both the category of respondents.

To analyze the relationship between the demographic variables and the percentage of investments a chi-square tests were performed.

Table 7: Results of Chi-Squared Tests

\begin{tabular}{|l|l|l|}
\hline Demographic Variables & Value & Asymp. Sig. (2-sided) \\
\hline Income & $2.332 \mathrm{E} 2$ & .000 \\
\hline Gender & 23.4578 & .078 \\
\hline Age & $2.452 \mathrm{E} 2$ & .000 \\
\hline Family Status & 7.385 & .001 \\
\hline Education & 2.4567 & .000 \\
\hline
\end{tabular}

The results of the chi-squared tests (Table 7) shows that there is a relationship between income, age, education and family status of an individual on the investments. However, gender was not found to have any relationship to investment.

A t-test was performed to determine if there was a significant difference between the respondent groups and their investments. The results (Table 8) show that there is a significant difference between the respondent groups and their investments.

Table 8: Independent sample T test between respondent groups \& investment

\begin{tabular}{|c|c|c|c|c|c|}
\hline & 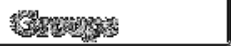 & 䈪 & 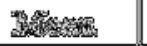 & 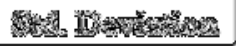 & 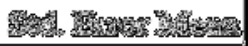 \\
\hline \multirow[t]{2}{*}{ A } & 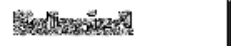 & $8 x$ & In & צy & 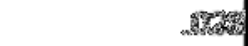 \\
\hline & 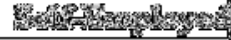 & $\mathrm{d}$ & 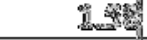 & 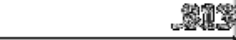 & $y_{0}$ \\
\hline
\end{tabular}




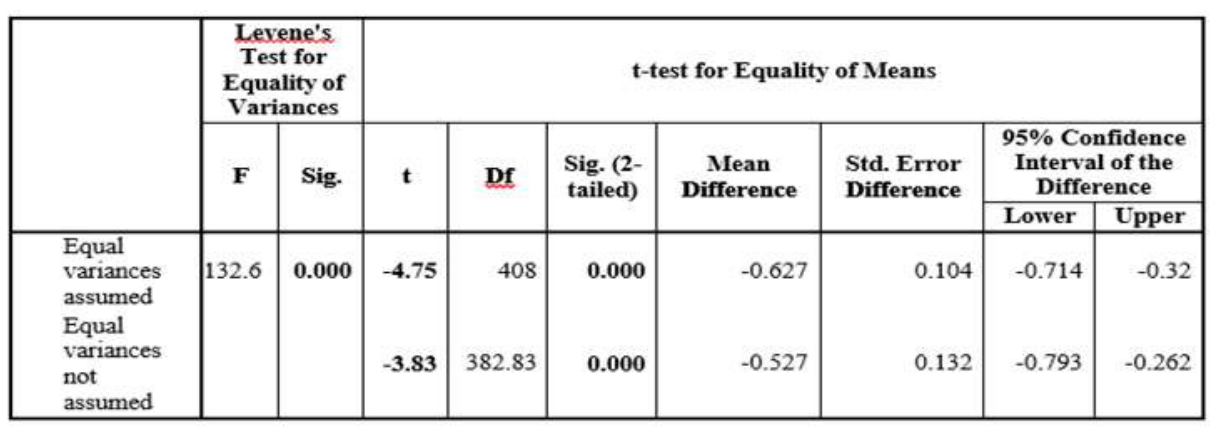

\section{Findings and Conclusion}

The study was conducted to determine the investment preferences and the factors that influence the investments of individuals. The study focused on two category of respondents, namely salaried and non-salaried class. The findings from the study show that income, age, family status and education influence the investment of respondents. Gender was however not an influencer. The study also showed that there were significant differences between the salaried and the self-employed in terms of the investments. The most preferred investment option by both the salaried and self-employed was fixed deposits. Despite the growth in technology and information availability about technology based investments, avenues such as crypto and derivatives were not preferred by the respondents. The primary motive for investment for the self-employed was generation of return whereas for the salaried it was taxsavings. Increasing the level of awareness about the new avenues that are available for investments will help investors to gain better returns. High risk seekers could be more educated over the share market opportunities to appreciate theirwealth.

\section{References}

[1] Antonides, G., \& Van Der Sar, N. L. (1990). Individual expectations, risk perception and preferences in relation to investment decision making. Journal of Economic Psychology, Vol. 11, No. 2, pp. 227-245.

[2] Awais, M., Laber, M. F., Rasheed, N., \& Khursheed, A. (2016). Impact of financial literacy and investment experience on risk tolerance and investment decisions: Empirical evidence from Pakistan. International Journal of Economics and Financial Issues, Vol. 6, No. 1, pp. 73-79.

[3] Bajtelsmit, V. L., \& Bemasek, A. (1996). 'Why do women invest differently than men?. Financial Counseling and Planning, Vol. 7, pp. 1-10

[4] Bhatt, K. A., \& Bhatt, K. (2012). 'Effects of investor occupation and education on choice of investment: An empirical study in India'. International Journal of Management, Vol. 29, No. 4, pp. 439-453.

[5] Bialowolski, P., \& Weziak-Bialowolska, D. (2014). 'External factors affecting investment decisions of companies'. Economics, Vol. 8, No. 1. pp. 20140011. Available at: https://doi.org/10.5018/economics-ejournal.ja.2014-11

[6] Chaurasia, P. (2017). 'A Study of Investment Preferences of Investors'. International Journal of Application or Innovation in Engineering \& Management (IJAIEM), Vol. 6, No. 7, pp. 29-36. 
[7] Jain, A. K., \& Joy, A. (1997). 'Money matters: An exploratory study of the socio-cultural context of consumption, saving, and investment patterns'. Journal of Economic Psychology, Vol. 18, No. 6, pp. 649-675.

[8] Kumawat, A. and Parkar, A. (2020). 'Study on Investment Pattern and the Factors Influencing Investment Decisions of an Individual'. Shodh Sarita, Vol. 7, No. 25, pp. 237-244.

[9] Ramanujam, V., \& Chitradevi, K. (2012). 'A study on impact of socio-economic profile on investment pattern of salaried and business people in Coimbatore city'. International journal of management \& information technology, Vol. 2, No. 1, pp. 67-77.

[10] Shukla, N. S. (2016). Investors Preference towards Investment Avenues with Special Reference to Salaried Personnel in North Gujarat Region. International Journal for Science and Research in Technology, Vol. 2, No. 1, pp. 43-49.

[11] Viscusi, W. K., Phillips, O. R., \& Kroll, S. (2011). 'Risky investment decisions: How are individuals influenced by their groups?’. Journal of Risk and Uncertainty, Vol. 43, No. 2, pp. 81106. 